\title{
NIEMIECKIE PRZEPISY W ZAKRESIE SZACOWANIA PODSTAWY OPODATKOWANIA W ORDYNACJI PODATKOWEJ - WNIOSKI DLA POLSKI - WYBRANE ASPEKTY
}

\section{Wstęp}

Jednym z podstawowych aktów prawnych obowiązujących w polskim systemie podatkowym jest ordynacja podatkowa, która obowiązuje od 1998 r. Już w momencie jej wejścia w życie część przepisów została poddana krytyce. Co więcej, wysuwane są postulaty głębokiej nowelizacji ordynacji podatkowej, a nawet powstają jej nowe projekty ${ }^{1}$. Ordynacja podatkowa stanowi składową nie tylko polskiego systemu podatkowego, ale występuje także w innych krajach. Jednym z państw o rozwiniętym systemie podatkowym zbliżonym od polskiego są Niemcy. Ordynacja podatkowa pełni także tam rolę podstawowego aktu prawa podatkowego. Reguluje ona różne kwestie dotyczące opodatkowania, funkcjonowania podatników, jak i organów podatkowych.

Jednym z elementów występujących zarówno w polskiej, jak i niemieckiej ordynacji podatkowej są przepisy określające zasady szacowania podstawy opodatkowania. $\mathrm{W}$ niektórych aspektach różnią się one między sobą ${ }^{2}$. Celem opracowania jest ocena możliwości wykorzystania niemieckich rozwiązań dotyczących szacowania podstawy opodatkowania określonego $\mathrm{w}$ ordynacji podatkowej w polskim systemie podatkowym. Niemieckie regulacje zawarte w ordynacji podatkowej obejmują kilka różnych zagadnień związanych z szacowaniem. Należą do nich: określenie przesłanek szacowania podstawy opodatkowania, wskazanie szczegółowych warunków szacowania w przypadku stosowania cen transferowych, nakładania sankcji, metod szacowania.

\footnotetext{
* Adiunkt, Instytut Finansów, Uniwersytet Łódzki.

${ }^{1}$ H. Dzwonkowski, Koncepcja budowy Ordynacji podatkowej w ukladzie funkcjonalnym (zarys), „Monitor Podatkowy” 2012, nr 10, s. 28-34.

${ }^{2}$ Por. art. 162 Abgabenordnung, Gesetz vom 16.03.1976 BGBl. I s. 613; art. 23 ustawy z dnia 29 sierpnia 1997 r. Ordynacja podatkowa t.j., Dz.U. 2012, poz. 749 z późn. zm.
} 


\section{Przeslanki szacowania podstawy opodatkowania}

Określając przyczyny szacowania podstawy opodatkowania, niemieckie przepisy nakazują generalnie ich wykorzystanie w przypadku niemożliwości obliczenia (ustalenia) podstawy opodatkowania ${ }^{3}$.

Warto zwrócić uwagę, że jest to podstawowa zasada, która ma swoje rozwinięcie $w$ dalszych regulacjach ordynacji podatkowej oraz przepisach zawartych innych aktach prawnych. Możliwość skorzystania $\mathrm{z}$ instytucji szacowania określonego w ordynacji podatkowej wykracza poza prawo podatkowe. Może być podstawą do zastosowania szacowania np. w prawie celnym. Co więcej, jako obowiązująca generalna reguła daje możliwość przeprowadzenia szacunku, (oczywiście w ramach zasad określonych w ordynacji podatkowej) w różnych elementach systemu podatkowego chyba, że poszczególne przepisy wykluczają wprost możliwości zastosowania oszacowania na podstawie ordynacji ${ }^{4}$. Zatem omawiany przepis jest także podstawą prawną do przeprowadzania szacowania konkretnego elementu konstrukcji w poszczególnych podatkach. Przykładowo jeśli podatnik ponosi koszty, które tylko w pewnym są związane z prowadzoną działalnością gospodarczą, to w celu ustalenia - faktycznie oszacowania kwoty, o jaką może pomniejszyć przychody, stosuje normy wynikające $\mathrm{z}$ ordynacji podatkowej ${ }^{5}$.

Regulacje dodatkowo wskazują na szczegółowe powody szacowania podstawy opodatkowania. Są one dosyć liczne. Organy podatkowe mogą ustalać podstawę opodatkowania w drodze szacunku, jeżeli podatnik nie składa wystarczających wyjaśnień związanych z udostępnianiem informacji, nie podaje szerszych informacji lub odmawia złożenia przyrzeczenia potwierdzającego prawdziwość udzielonych informacji. Przyczyną szacowania może być naruszenie obowiązku współdziałania z organami podatkowymi. Innym powodem jest brak udostępnia ewidencji podatkowych, nieprowadzenie albo nieudostępnianie przewidzianych przepisami ksiąg podatkowych. Szacowanie jest również uzasadnione, jeśli przedstawione ewidencje nie były sporządzone w przewidzianych w przepisach terminach ewentualnie nie są rzetelnie prowadzone. Regulacje jako powód szacowania wskazują sytuacje, gdy powstają faktyczne wskazania do uznania za nieprawdziwe lub niekompletne informacje podane przez podatnika, które to informacje dotyczą podlegających opodatkowaniu dochodów lub

\footnotetext{
${ }^{3}$ Por. art 162 par. 1 Abgabenordnung; R. Witczak, Die Schätzung der Besteuerungsgrundlage der Vergleich der Vorschriften in Deutschland und Polen, [w:] A. Warda, Z. Weigt (Hrsg.), Nachwuchswissenschaftler präsentieren ihre Forschung, Wydawnictwo UŁ, Łódź 2009, s. 116.

${ }^{4}$ R. Rüsken, F. Klein (Hrsg.), Schätzung von Besteuerungsgrundlagen, Abgabenordnung, 11. Auflage, Verlag C.H. Beck, München 2012 wyd. el. (dostęp 22.06.2013).

5 J. Urban, Besteuerung von Dienstreisen - Aufgabe des Aufteilungs- und Abzugsverbots durch den BFH, Der Sachverständige - Fachzeitschrift für Sachverständige, Kammern, Gerichte und Behörden, 2010, Nr 4 wyd. el. Beck (dostęp 21.06.2013).
} 
przyrostu majątku ${ }^{6}$. Można ogólnie stwierdzić, że szacowanie podstawy opodatkowania ma miejsce wtedy, gdy podatnik nie udostępnia wystarczających informacji o rodzaju dokonywanych transakcji. Celem takiego szacowania jest opodatkowanie zysków, jakie zostałyby osiągnięte, gdyby zastosowano faktyczne ceny sprzedawanych dóbr i usług ${ }^{7}$.

W literaturze wskazuje się, iż przepisy dotyczące szacowania podstawy opodatkowania z założenia nie mogą być precyzyjnie sformułowane. Pozostawiają pewien margines na interpretacje. W efekcie mogą być one różnie rozumiane, co prowadzi do sporów odnośnie do ich wykładni ${ }^{8}$.

Warto zwrócić uwagę na występowanie szczególnej przyczyny szacowania podstawy opodatkowania. Jest nią naruszenie obowiązku współdziałania podatnika $\mathrm{z}$ organami podatkowymi. Jest to specyficzna instytucja $\mathrm{w}$ niemieckim prawie podatkowym ustanowiona w ordynacji podatkowej ${ }^{9}$. Przy czym należy zauważyć, że obowiązku współdziałania podatnika z organami podatkowymi nie wolno rozpatrywać w odosobnieniu od innych elementów systemu podatkowego, które służyć mają ocenie, czy podatnik wywiązuje się prawidłowo z obowiązków podatkowych. Szeroki zakres takich instrumentów obejmuje różne obowiązki, jakie są nałożone na podatników, ale także i ułatwienia. Zaliczyć do nich można dostarczanie informacji organom podatkowym, możliwość zawierania uprzednich porozumień w zakresie cen transferowych. Ich wykonywanie służyć ma nie tylko samemu zrealizowaniu w odpowiedniej wysokości zobowiązania podatkowego, ale uczynienia tego we współpracy $\mathrm{z}$ podatnikiem. Podstawową ideą wprowadzenia tego typu przepisów (obejmujących również obowiązek współdziałania) jest nastawienie się organów podatkowych nie na konfrontacje, ale na realizację zobowiązania podatkowych we współpracy z podatnikiem. Przysłużyć się one też mają do zwiększenia zaufania do organów podatkowych oraz przejrzystości całego procesu stosowania prawa podatkowego $^{10}$.

Występowanie jako jednego z powodów szacowania naruszenia obowiązku współdziałania podatnika $\mathrm{z}$ organami podatkowymi należy odczytywać jako

${ }^{6}$ Por. art. 162 ust. 2 Abgabenordnung; R. Witczak, Die Schätzung..., s. 116.

${ }^{7}$ Bundesministerium der Finanzen, Grundsätze für die Prüfung der Einkunftsabgrenzung zwischen international verbundenen Unternehmen und zwischen anderen nahe stehenden Personen mit grenzüberschreitenden Geschäftsbeziehungen in Bezug auf Berichtigungen, Ermittlungsund Mitwirkungspflichten sowie Verständigungs- und EUSchiedsverfahren (Verwaltungsgrundsätze - Verfahren) http://www.rws-verlag.de/volltext-2004/04bmf01pdf.pdf (dostęp 16.08.2008).

${ }^{8}$ R. Seer, Besteuerungsverfahren im 21. Jahrhundert, „Finanz-Rundschau“ 2012, Nr 21, http://www.wiso-net.de/webcgi?START=A60\&DOKV_DB=ZGEN\&DOKV_NO=FINRFR.

2012.21.A.03\&DOKV_HS=0\&PP=1 (dostęp 26.06.2013).

${ }^{9}$ Por. art. 90 Abgabenordnung.

${ }^{10}$ S. Greli, S. Kiesow, Tax compliant transfer pricing, „Deutsche Steuer-Zeitung“ 2013, H. 11, http://www.wiso-net.de/webcgi?START=A60\&DOKV_DB=ZGEN\&DOKV_NO=DSTZC8 CB869B7FE5838650A60CF1844023C7\&DOKV_HS=0\&PP=1 (dostęp 24.06.2013). 
rozwiązania systemowe. Skoro podatnik nie chce współdziałać z organami podatkowymi, to musi ponosić tego konsekwencje. Jedną $\mathrm{z}$ nich jest prawo organów podatkowych do szacowania. Teoretycznie samo szacowanie nie jest rodzajem sankcji. Jednakże może być tak odbierane przez podatników. Skoro nie zawsze jest możliwe w drodze szacunku ustalenie dokładne takiej wartości podatku, jaka faktycznie ma miejsce, to może dojść do przeszacowania. To jest już odbierane jako forma sankcji. $Z$ drugiej strony, jeśli podatnik nie chce współpracować $\mathrm{z}$ organami podatkowymi, to muszą one $\mathrm{w}$ jakiś sposób dokonać ustalenia podstawy opodatkowania. Ordynacja podatkowa przewiduje w takiej sytuacji użycie szacunku.

\section{Szczególowe warunki szacowania w przypadku stosowania cen transferowych}

Regulacje zawarte w ordynacji podatkowej są również podstawą do szacowania $\mathrm{w}$ przypadku stosowania cen transferowych $\mathrm{w}$ celu nielegalnego zmniejszenia obciążeń podatkowych. Zgodnie z regulacjami, jeśli podatnik nie przedstawia dokumentacji dotyczącej cen transferowych, przedstawia dokumentacje nie odpowiadającą przepisom, ewentualnie przedstawia ją po upływie terminów określonych w odrębnych przepisach ordynacji podatkowej, to daje uprawnienie do uznania przez organy podatkowe, że dochody osiągane w kraju są wyższe od dochodów wykazywanych $\mathrm{w}$ deklaracjach podatkowych. W efekcie można szacować podstawę opodatkowania w związku ze stosowaniem cen transferowych $^{11}$. Regulacje te są zawarte w ordynacji podatkowej, ale stanowią przepis szczególny w stosunku do ogólnej reguły szacowania podstawy opodatkowa$\mathrm{nia}^{12}$. Jest to bez wątpienia różnica $\mathrm{w}$ porównaniu $\mathrm{z}$ polskimi przepisami. Same regulacje nie określają dokładnych zasad szacowania w tym zakresie. Jednakże należy zwrócić uwagę, że niemieckie organy podatkowe wydają wytyczne w zakresie stosowania regulacji dotyczących szacowania dochodu przerzucanego do innych podmiotów ${ }^{13}$. Warto zwrócić uwagę, że wytyczne są bardzo

${ }^{11}$ Por. art. 162, ust. 3 Abgabenordnung; M. Babi, H. Baumhoff, R. Bláhová i in., Verrechnungspreis-Dokumentationspflichten in Deutschland, Österreich und in ausgewählten osteuropäischen Staaten, „Internationales Steuerrecht“ 2010, Nr 37, wyd. el. baza danych Beck (dostęp 21.06.2013).

${ }^{12}$ G. Kraft (Hrsg.), Außensteuergesetz, Kommentar, München 2009, C.H. Beck wyd. el. (dostęp 22.06.2013).

${ }^{13}$ Por. Grundsätze zur Anwendung des Außensteuergesetzes z 14.05.2004 r. sygn. IV B 4 - S 1340-11/04 http://www.bundesfinanzministerium.de/Content/DE/Downloads/BMF_Schreiben/ Internationales_Steuerrecht/Allgemeine_Informationen/020.pdf?_blob=publicationFile\&v $=6$ (dostęp 02.07.2013); Schreiben betr. Grundsätze für die Prüfung der Einkunftsabgrenzung zwischen nahe stehenden Personen in Fällen von grenzüberschreitenden Funktionsverlagerungen (Verwaltungsgrundsätze Funktionsverlagerung) z 13.10.2010 r., Beck wyd el. (dostęp 22.06.2013). 
obszerne i szczegółowe. Poszczególne wydane wytyczne mogą dotyczyć tak jednostkowej kwestii dotyczącej cen transferowych jak ustalanie funkcji pełnionych pomiędzy powiązanymi przedsiębiorstwami. Opierają się one na wytycznych wydanych przez OECD. Wskazują na czynniki, jakie należy uwzględnić przy przeprowadzaniu szacowania. Pokazują przykłady sytuacji zastosowania szacowania. Zawarte w wytycznych przykłady pokazują wyliczenia poziomów cen, które mogą być wykorzystane do korygowania cen transferowych i w efekcie ustalania dochodu ${ }^{14}$.

Warto rozważyć wprowadzenie do polskich przepisów powyższego rozwiązania. W Polsce występuje odrębne rozporządzenia dotyczące szacowania w przypadku stosowania cen transferowych ${ }^{15}$, jednakże $\mathrm{w}$ porównaniu $\mathrm{z}$ niemieckimi wytycznymi są one znacznie uboższe. Oficjalnie publikowane wytyczne mogą być pomocne nie tylko dla organów podatkowych stosujących przepisy, ale także podatników. Dają one podstawy do oceny, czy postępowanie służb skarbowych jest prawidłowe. Umożliwiają podatnikom również ocenę, czy przyjęte przez nich standardy ustalania cen transferowych są zbieżne z regułami stosowanymi przez organy podatkowe. Ograniczać to może ryzyko popełnienia błędu. Warto taką praktykę przyjąć także w Polsce. Co prawda, może powstawać wątpliwość, czy tworzenie tak obszernych regulacji nie jest elementem zwiększającym skomplikowanie systemu. Jednak należy mieć na uwadze, że korekta cen transferowych i szacownie dochodu jest samo w sobie skomplikowaną materią. Wytyczne OECD dotyczące cen transferowych wydawane w kolejnych latach też są coraz bardziej obszerne ${ }^{16}$. Dlatego wydanie tego typu wytycznych dla polskich organów wydaje się być jak najbardziej właściwe.

\section{Nakładanie sankcji}

W ramach regulacji dotyczących szacowania podstawy opodatkowania wprowadzono szczególne rozwiązanie dotyczące nieprzedłożenia w terminie dokumentacji sporządzanej na potrzeby stosowania cen transferowych. Polega

${ }^{14}$ Schreiben betr. Grundsätze...

${ }^{15}$ Rozporządzenie Ministra Finansów z dnia 10 września 2009 r. w sprawie sposobu i trybu określania dochodów osób prawnych w drodze oszacowania oraz sposobu i trybu eliminowania podwójnego opodatkowania osób prawnych w przypadku korekty zysków podmiotów powiązanych (Dz.U. 2009, nr 160, poz. 1268 z późn. zm.); Rozporządzenie Ministra Finansów z dnia 10 września 2009 r. w sprawie sposobu i trybu określania dochodów osób fizycznych w drodze oszacowania oraz sposobu i trybu eliminowania podwójnego opodatkowania osób fizycznych w przypadku korekty zysków podmiotów powiązanych (Dz.U. 2009, nr 160, poz. 1267 z późn. zm.).

${ }^{16}$ Por. OECD, Wytyczne $w$ sprawie cen transferowych dla przedsiębiorstw wielonarodowych oraz administracji podatkowych, Lex a Wolters Kluwer business, Warszawa 2012; OECD, Transfer Pricing guidelines for multinational enterprises and tax administration, Paryż 2001; OECD, Verrechnungspreise und Multinationale Unternehmen. Bericht des Steuerausschuesses der OECD, 1979, Kolonia 1981. 
ono na nałożeniu swoistej sankcji - „dodatku” do wartości szacunku, jeżeli ewidencje związane $\mathrm{z}$ transakcjami $\mathrm{z}$ zagranicą nie zostaną przez podatnika przedłożone. Ma on charakter dodatkowego zobowiązania podatkowego. Jeżeli podatnik narusza obowiązek prowadzenia ewidencji, nie przedkłada jej pomimo wezwań administracji skarbowej, ewentualnie czyni to po wyznaczonych terminach lub jest ona nierzetelna, to organy podatkowe maja prawo do nałożenia „dodatku” Nałożenie tego „dodatku” jest aktem administracyjnym ${ }^{17}$. Przy czym warto zauważyć, że termin na przedłożenie dokumentacji został określony na 60 dni od momentu zażądania jej okazania. Zarazem w przepisach przewidziano zakres sporządzanej dokumentacji oraz pewne wyjątki co do sposobu prowadzenia dokumentacji oraz terminu jej przedłożenia ${ }^{18}$. Obecnie obowiązujące regulacje określają rozmiary tej kary. Jej minimalna wartość wynosi 5000 euro. Zarazem zgodnie z przepisami wartość sankcji ustala się pomiędzy 5 a $10 \%$ dodatkowej kwoty dochodów, jaka została ustalona w wyniku skorygowania stosowanych przez podatnika cen transferowych. W przypadku opóźnienia w złożeniu dokumentacji spełniającej wymagania określone w odrębnych przepisach istnieje możliwość dodatkowej sankcji. Sama kara z tego powodu może wynosić nawet 1 mln euro, minimum jednak 100 euro za każdy pełen dzień przekroczenia terminu złożenia dokumentacji. Dodatkowo w przepisach określono szczegółowe kwestie nakładania „dodatku”, a także możliwości jego uniknięcia ${ }^{19}$.

Wprowadzanie swoistych sankcji w ordynacji podatkowej może być dyskusyjne. Oczywiście, na omawiane rozwiązania należy patrzeć przez pryzmat całościowych norm wynikających z niemieckiej ordynacji podatkowej. Mają one służyć wykonaniu obowiązków nałożonych właśnie przez ordynację podatkową. Zasadniczo przewidziane są w niej regulacje dotyczące skutków popełniania oszustw podatkowych, w tym nakładania kar.

Ogólnie należy mieć na uwadze, że sankcje nie zawsze muszą wynikać z przepisów prawa karnego. Ich występowanie może mieć różnorodny charakter. Jednakże przeniesienie powyższego rozwiązania wprost do polskiej ordynacji podatkowej niekoniecznie musi być uzasadnione. Generalnie ${ }^{20}$, w polskiej ordynacji podatkowej nie przyjęto jako reguły, aby sankcje były tam umiejscowione. W przypadku nowelizacji (lub uchwalenia nowego kodeksu podatkowego) nie należy zalecać ujęcia w przepisach dotyczących szacowania podstawy opodatkowania norm umożliwiających nakładanie sankcji. Oczywiście, nie można wykluczyć powstania takiej koncepcji ordynacji podatkowej, która z założenia miałaby również obejmować wszelkie regulacje o charakterze karnym.

\footnotetext{
${ }^{17}$ Art. 162, ust. 4 Abgabenordnung; R. Witczak, Die Schätzung..., s. 117.

${ }^{18}$ Art. 90, ust. 3 Abgabenordnung; M. Babi, H. Baumhoff, R. Bláhová i. in., Verrechnungspreis-...

${ }^{19}$ Art. 162, ust. 4 Abgabenordnung; M. Babi, H. Baumhoff, R. Bláhová i. in., Verrechnungspreis-...

${ }^{20}$ Poza wyjątkiem art. 262 ustawy z dnia 29 sierpnia 1997 r. Ordynacja podatkowa...
} 
Wówczas niemieckie rozwiązania mogłyby służyć jako przykład wprowadzenia tego typu sankcji. Pozostaje jednak wątpliwość, czy zawieranie w ordynacji kar jest najlepszą propozycją.

\section{Metody szacowania podstawy opodatkowania}

Według niemieckich przepisów przy szacowaniu należy uwzględnić wszelkie okoliczności, jakie mogą mieć znaczenie ${ }^{21}$. Identyczne sformułowanie występuje $\mathrm{w}$ polskim systemie prawnym. Niemieckie normy nie określają wprost metod, jakie mogą zastosować organy podatkowe. W literaturze wskazuje się na możliwość wykorzystania różnych metod szacowania podstawy opodatkowania ${ }^{22}$.

Ze względu na swój szeroki charakter szacowanie dotyczyć może także przypadków osiągania nieujawnionych źródeł dochodów. Regulacje nie wymieniają wprost metod szacowania, ale uznaje się za dopuszczalne stosowanie metod, które służą ustaleniu dochodu w przypadku nieujawnionych źródeł dochodów. W polskim systemie prawnym jest to instytucja odrębnie uregulowana $\mathrm{w}$ podatku dochodowym od osób fizycznych. Warto zwrócić uwagę, że zawiera ona elementy szacowania ${ }^{23}$. Wskazane byłoby ujęcie w jednym akcie prawnym przypadków szacowania. Wówczas w polskiej ordynacji podatkowej należałoby określić zasady ustalenia podstawy opodatkowania w oparciu o wartość poniesionych wydatków, jako jednej z dozwolonych metod szacunku.

Wydaje się, że polskie regulacje, które wymieniają metody szacowania podstawy opodatkowania, bardzo krótko je opisując ${ }^{24}$, są lepszym sposobem sformułowania przepisów. Dają większą ochronę podatników. Są też pewną wskazówką dla organów podatkowych. Nie należy zatem korzystać z niemieckich wzorców w tym zakresie i skreślać regulacji wymieniających metody szacowania podstawy opodatkowania.

Jednakże warto zauważyć, że omawiane niemieckie przepisy są podstawą do wydawania wytycznych $\mathrm{w}$ zakresie stosowanych metod szacunku przez niemieckie organy podatkowe. Przykładowo można wskazać wytyczne w związku z szacowaniem podstawy opodatkowania przy niektórych popularnych rodzajach działalności gospodarczej. Zarazem tego typu formy działalności są narażone na próby nielegalnego zmniejszenia podatku poprzez zatajenie całości lub części przychodów. Zalicza się do nich przykładowo piekarnie, restauracje. W wytycz-

${ }^{21}$ Art. 162, ust. 1 Abgabenordnung.

${ }^{22}$ Zob. szerzej R. Kuehn, A. von Wedelsaedt, Abgabenordnung und Finanzgerichtsordnung, Schaeffer-Poeschel Verlag, Stuttgart, s. 403.

${ }^{23}$ Por. art. 20 ust. 3 ustawy z dnia 26 lipca 1991 r. O podatku dochodowym od osób fizycznych (tekst jednolity Dz.U. 2012, poz. 361 z późn. zm.).

${ }^{24}$ Por. art. 23 par. 3 i 4 ustawy z dnia 29 sierpnia 1997 r. Ordynacja podatkowa... 
nych zawarte są dane dotyczące poprzedniego roku odnośnie do średniego dochodu i podatku, jaki płaciły określonego rodzaju przedsiębiorstwa. Zwykle wytyczne są wydawane na określony rok z informacjami dotyczącymi poprzedniego roku. W wytycznych zawarte są również zasady ustalania przychodów $\mathrm{z}$ otrzymanych nieodpłatnie towarów ${ }^{25}$.

Takie rozwiązanie ma zalety i wady. Podatnik może się bronić, że jego sytuacja jest odmienna od ustalonej średniej. W efekcie $i$ tak organy podatkowe nie będą mogły skorzystać z tego typu danych, lecz muszą same ustalać porównywalne przedsiębiorstwa w celu oszacowania podstawy opodatkowania. Jednakże wystąpić mogą sytuacje, kiedy dany podatnik nie współpracuje z organami podatkowymi, nie udziela informacji lub też informacje są wątpliwe lub nieprawdziwe. Wówczas można potraktować zawarte w wytycznych dane, jako podstawę, która może być wykorzystana do przeprowadzenia szacowania. Sam fakt istnienia takiego źródła może skłaniać niektórych podatników do udziału w wyjaśnieniu dokładnym stanu faktycznego. Zatem można zalecić przygotowywania w podobnym zakresie wytycznych przez polskie Ministerstwo Finansów. Rozważyć można nawet krok dalszy - rozszerzenie tych wytycznych. Można wzorować się także na niemieckich wytycznych dotyczących cen transferowych. Polskie wytyczne mogłyby zawierać dokładny opis metod szacowania podstawy opodatkowania (niekoniecznie związanych tylko cenami transferowymi). Wymienione mogłyby być czynniki, jakie należy uwzględnić przy szacowaniu podstawy opodatkowania. Również warto zawrzeć przykłady zastosowania poszczególnych metod. Opublikowanie takich wytycznych może być pomocne zarówno dla organów podatkowych stosujących przepisy, jak i dla podatników. Pracownikom organów ułatwić mogą wykorzystanie metod szacunku. Natomiast podatnikom dają podstawę do oceny, czy postępowanie służb skarbowych jest prawidłowe.

\section{Zakończenie}

Niemieckie regulacje dotyczące szacowania podstawy opodatkowania zawarte w ordynacji podatkowej mogą w pewnym zakresie służyć jako przykład rozwiązań, które warto zastosować w polskim systemie.

Przy wykorzystywaniu niemieckich doświadczeń powinno się mieć na uwadze, iż tworzeniu regulacji podatkowych o charakterze ogólnego prawa powinny przyświecać myśli przewodnie, cele, jakim mają służyć poszczególne rodzaje norm. Analizując niemieckie przepisy dotyczące szacowania podstawy opodatkowania, widać powiązania systemowe zarówno z innymi regulacjami zawartymi w ordynacji podatkowej, jak i innymi aktami prawnymi. Taki sposób tworze-

\footnotetext{
${ }^{25}$ Por. Richtsatzsammlung 2011, wyd. el. Baza danych Beck (dostęp 22.06.2013).
} 
nia przepisów oczywiście warto przenieść w przypadku nowelizacji lub uchwalania nowej ordynacji podatkowej. Również niektóre zapisy mogą być wykorzystane w polskich normach. Warto jednak dokładnie je rozważyć przy pracach, jakie są lub będą prowadzone w związku z nowelizacją lub uchwalaniem nowej ordynacji podatkowej. Jednym z elementów, który jest godny rozważenia, jest uznanie szacowania podstawy opodatkowania $\mathrm{w}$ ordynacji podatkowej jako podstawy do dokonywania wszelkiego szacunku w prawie podatkowym. Oznacza to również objęcie regułami szacowania podstawy opodatkowania w ordynacji podatkowej ustalenia dochodu z nieujawnionych źródeł przychodów czy też szacowania w związku z wykorzystywaniem cen transferowych. Nie wyklucza to zastosowania szczególnych sposobów ustalenia podstawy opodatkowania, jeśli konkretne przepisy będą tak stanowić. Możliwe jest stworzenie w ramach instytucji szacowania zawartej $\mathrm{w}$ ordynacji reguł dotyczących tylko niektórych zagadnień jak np. ustalenie dochodu $\mathrm{w}$ drodze szacunku w przypadku stosowania cen transferowych. Godne polecenia jest również wydawanie bardzo szczegółowych wytycznych. Mogą być one odrębne dla przedsiębiorstw stosujących ceny transferowe lub innych przypadków, kiedy następuje szacowanie. Pomocne mogą być zarówno dla podatników, jak i organów podatkowych.

Jednak nie wszystkie przepisy powinny być przenoszone do polskiego systemu podatkowego. Należy uznać, że regulacji dotyczących nakładania sankcji za nieskładanie dokumentacji podatkowej nie warto zamieszczać w polskim odpowiedniku ordynacji podatkowej. Nie oznacza to, że niektóre przepisy dotyczące dokumentacji w przypadku stosowania cen transferowych nie mogłyby być przeniesione do ustaw o podatkach dochodowych. Takie działania wymagałyby przeprowadzenia dokładnej analizy ich skutków. Przeniesienie sankcji do ordynacji podatkowej może być zasadne w sytuacji, gdy zostałaby wdrożona koncepcja ordynacji zawierającej również wszelkie sankcje związane ze stosowaniem przepisów podatkowych.

\section{Literatura}

Abgabenordnung, Gesetz vom 16.03.1976 BGBl. I.

Bundesministerium der Finanzen, Grundsätze für die Prüfung der Einkunftsabgrenzung zwischen international verbundenen Unternehmen und zwischen anderen nahe stehenden Personen mit grenzüberschreitenden Geschäftsbeziehungen in Bezug auf Berichtigungen, Ermittlungs- und Mitwirkungspflichten sowie Verständigungs- und EUSchiedsverfahren (Verwaltungsgrundsätze - Verfahren), http://www.rws-verlag.de/volltext-2004/04bmf01pdf.pdf.

Babi M., Baumhoff H., Bláhová R i in., Verrechnungspreis-Dokumentationspflichten in Deutschland, Österreich und in ausgewählten osteuropäischen Staaten, „Internationales Steuerrecht“ 2010, Nr 37.

Dzwonkowski H., Koncepcja budowy Ordynacji podatkowej w układzie funkcjonalnym (zarys), „Monitor Podatkowy” 2012, nr 10. 
Greli S., Kiesow S., Tax compliant transfer pricing, „Deutsche Steuer-Zeitung“ 2013, Nr 11.

Grundsätze zur Anwendung des Außensteuergesetzes z 14.05.2004 r., sygn. IV B 4 - S 1340 11/04 http://www.bundesfinanzministerium.de/Content/DE/Downloads/BMF_Schreiben/ Internationales_Steuerrecht/Allgemeine_Informationen/020.pdf?_blob=publicationFile\& $\mathrm{v}=6$.

Kraft G (Hrsg.), Außensteuergesetz, Kommentar, C.H. Beck, München 2009.

Kuehn R., von Wedelsaedt A., Abgabenordnung und Finanzgerichtsordnung, Schaeffer-Poeschel Verlag, Stuttgart.

OECD, Transfer Pricing guidelines for multinational enterprises and tax administration, Paris 2001.

OECD Verrechnungspreise und Multinationale Unternehmen. Bericht des Steuerausschuesses der OECD 1979, Kolonia 1981.

OECD, Wytyczne $w$ sprawie cen transferowych dla przedsiębiorstw wielonarodowych oraz administracji podatkowych, Lex a Wolters Kluwer business, Warszawa 2012.

Richtsatzsammlung 2011, wyd. el.

Rozporządzenie Ministra Finansów z dnia 10 września 2009 r. w sprawie sposobu i trybu określania dochodów osób prawnych w drodze oszacowania oraz sposobu i trybu eliminowania podwójnego opodatkowania osób prawnych w przypadku korekty zysków podmiotów powiązanych (Dz.U. 2009, nr 160, poz. 1268 z późn. zm.).

Rozporządzenie Ministra Finansów z dnia 10 września 2009 r. w sprawie sposobu i trybu określania dochodów osób fizycznych w drodze oszacowania oraz sposobu i trybu eliminowania podwójnego opodatkowania osób fizycznych w przypadku korekty zysków podmiotów powiązanych (Dz. U. 2009, nr 160, poz. 1267 z późn. zm.).

Rüsken R., Klein F. (Hrsg.), Schätzung von Besteuerungsgrundlagen, Abgabenordnung, 11. Auflage, Verlag C.H. Beck, München 2012 wyd. el.

Schreiben betr. Grundsätze für die Prüfung der Einkunftsabgrenzung zwischen nahe stehenden Personen in Fällen von grenzüberschreitenden Funktionsverlagerungen (Verwaltungsgrundsätze Funktionsverlagerung) z 13.10.2010 r., wyd el.

Seer R., Besteuerungsverfahren im 21. Jahrhundert, „Finanz-Rundschau“ 2012, Nr 12.

Urban J., Besteuerung von Dienstreisen - Aufgabe des Aufteilungs- und Abzugsverbots durch den $B F H$, „Der Sachverständige - Fachzeitschrift für Sachverständige, Kammern, Gerichte und Behörden" 2010, Nr 4, wyd. el.

Ustawa z dnia 29 sierpnia 1997 r. Ordynacja podatkowa, tj., Dz.U. 2012, poz. 749 z późn. zm.).

Ustawa z dnia 26 lipca 1991 r. O podatku dochodowym od osób fizycznych (tekst jednolity Dz.U. 2012, poz. 361 z późn. zm.).

Witczak R., Die Schätzung der Besteuerungsgrundlage der Vergleich der Vorschriften in Deutschland und Polen, [w:], A. Warda, Z. Weigt (Hrsg.), Nachwuchswissenschaftler präsentieren ihre Forschung, Wydawnictwo UŁ, Łódź 2009.

\section{Streszczenie}

Zarówno polska jak i niemiecka ordynacja podatkowa zawiera przepisy dotyczące szacowania podstawy opodatkowania. Przedstawiono niemieckie przepisy w zakresie szacowania podstawy opodatkowania. Wskazano na przyczyny szacowania. Omówiono warunki szacowania w przypadku stosowania cen transferowych. Zaprezentowano zasady nakładania sankcji. Przedstawiono reguły dotyczące metod szacowania. W artykule oceniono możliwość wykorzystania niemieckich reguł związanych z szacowaniem podstawy opodatkowania w polskim systemie podatkowym. 


\section{Summary}

\section{THE GERMAN PROVISIONS ON ESTIMATNION OF TAX BASE IN TAX ORDINANCE - CONCLUSIONS FOR POLAND - SELECTED ISUESS}

Either the Polish and German tax ordinance have provisions concerning estimation of tax base. The German provisions on estimation of tax base were given. The causes of estimation of tax base were indicated. The conditions of estimation in case of transfer pricing were discussed. The rules of punishment were presented. The provisions of the methods of estimating of tax base was given. In the article the possibility of use the German provisions concerning estimation of tax base in the Polish tax system was discussed. 